\title{
Chemical composition and hygroscopic properties of aerosol particles over the Aegean Sea
}

\author{
S. Bezantakos ${ }^{1,2}$, K. Barmpounis ${ }^{3}$, M. Giamarelou ${ }^{1}$, E. Bossioli ${ }^{4}$, M. Tombrou ${ }^{4}$, N. Mihalopoulos ${ }^{5}$, K. Eleftheriadis ${ }^{2}$, \\ J. Kalogiros ${ }^{6}$, J. D. Allan ${ }^{7}$, A. Bacak ${ }^{7}$, C. J. Percival ${ }^{7}$, H. Coe ${ }^{7}$, and G. Biskos ${ }^{1,3}$ \\ ${ }^{1}$ Department of Environment, University of the Aegean, Mytilene 81100, Greece \\ ${ }^{2}$ ERL, Inst. of Nuclear Technology \& Radiation Protection, NCSR Demokritos, 15310 Ag. Paraskevi, Attiki, Greece \\ ${ }^{3}$ Faculty of Applied Sciences, Delft University of Technology, Delft 2628-BL, the Netherlands \\ ${ }^{4}$ Department of Physics, National and Kapodistrian University of Athens, Athens 15784, Greece \\ ${ }^{5}$ Department of Chemistry, University of Crete, Heraklion 71003, Greece \\ ${ }^{6}$ Institute of Environmental Research and Sustainable Development, National Observatory of Athens, Athens, Greece \\ ${ }^{7}$ School of Earth, Atmospheric and Environmental Science, The University of Manchester, Manchester, UK
}

Correspondence to: G. Biskos (biskos@aegean.gr, g.biskos@tudelft.nl)

Received: 16 January 2013 - Published in Atmos. Chem. Phys. Discuss.: 6 March 2013

Revised: 23 September 2013 - Accepted: 25 October 2013 - Published: 29 November 2013

\begin{abstract}
The chemical composition and water uptake characteristics of sub-micrometre atmospheric particles over the region of the Aegean Sea were measured between 25 August and 11 September 2011 within the framework of the AegeanGame campaign. High temporal-resolution measurements of the chemical composition of the particles were conducted using an airborne compact time-of-flight aerosol mass spectrometer (cToF-AMS). These measurements were performed during two flights from the island of Crete to the island of Lemnos and back. A hygroscopic tandem differential mobility analyser (HTDMA) located on the island of Lemnos was used to measure the ability of the particles to take up water. The HTDMA measurements showed that the particles in the dominant mode were internally mixed, having hygroscopic growth factors that ranged from 1.00 to 1.59 when exposed to $85 \%$ relative humidity. When the aircraft flew near the ground station on Lemnos, the cToF-AMS measurements showed that the organic volume fraction of the particles ranged from 43 to $56 \%$. These measurements corroborate the range of hygroscopic growth factors measured by the HTDMA during that time. Good closure between HTDMA and cToF-AMS measurements was achieved when assuming that the organic species were less hygroscopic and had an average density that corresponds to aged organic species. Using the results from the closure study, the cToF-AMS measurements were employed to determine vertical profiles of a rep-
\end{abstract}

resentative aerosol hygroscopic parameter $\kappa_{\text {mix }}$. Calculated $\kappa_{\text {mix }}$ values ranged from 0.19 to 0.84 during the first flight and from 0.22 to 0.80 during the second flight. Air masses of different origin as determined by back trajectory calculations can explain the spatial variation in chemical composition and $\kappa_{\text {mix }}$ values of the particles observed in the region.

\section{Introduction}

Atmospheric aerosol particles affect the global radiative balance of the earth by directly absorbing and scattering solar radiation (i.e. direct effect; Haywood and Boucher, 2000), and indirectly by acting as cloud condensation nuclei (i.e. indirect effect; Ogren and Charlson, 1992). Scattering and absorption of atmospheric particles strongly depends on their size and chemical composition, which are often characterised by high variability as a result of the large diversity of their sources and the different physicochemical processes they are involved in during their lifetime (Hallquist et al., 2009). The chemical composition of the particles also defines their hygroscopicity, i.e. their ability to take up water, which in turn can affect their interaction with incoming solar radiation. To predict the hygroscopic behaviour of pure or mixed inorganic particles one can use basic thermodynamic principles (e.g. Clegg et al., 1998). For particles that consist of organic 
species or mixtures of organic and inorganic compounds, however, existing knowledge does not allow accurate predictions of their hygroscopicity. This limited understanding is one of the greatest uncertainties in determining the role of atmospheric aerosols on climate.

To overcome the complexities involved in associating the chemical composition of atmospheric particles with their hygroscopic behaviour, Petters and Kreidenweis (2007) proposed the use of a single hygroscopic parameter $\kappa$. The value of $\kappa$ is zero for completely insoluble but wettable particles whose water activity is not affected by water adsorbed on their surface. For typical atmospheric soluble-salt particles such as ammonium sulfate or sodium chloride, the value of $\kappa$ is 0.53 and 1.12 , respectively, whereas for secondary organic aerosols (SOAs) it typically ranges between 0.0 and 0.2 (Petters and Kreidenweis, 2007). Using the parameter $\kappa$ and information about the hygroscopic behaviour of the pure chemical species, one can make a good first approximation of the water uptake characteristics of internally mixed particles.

Particles observed in remote areas are typically suspended in the atmosphere long enough to reach an internally mixed state through coagulation and condensation of gaseous species (Heintzenberg, 1989). This is typically the case for the wider area of eastern Mediterranean, and particularly the region over the Aegean Sea, during July and August when the prevailing northern winds (i.e. the Etesians) carry polluted air masses from central Europe, the Balkans (including northern Greece), and the Black Sea (Mihalopoulos et al., 1997; Lelieveld et al., 2002). The polluted air masses blend with natural primary and secondary particles, resulting in increased particle concentrations commonly observed in the region (Salisbury et al., 2003).

Although information about the size, the concentration, and the integrated chemical composition of particles found over the southern Aegean region has been extensively reported in the literature (e.g. Koulouri et al., 2008; Kalivitis et al., 2008), high temporal resolution measurements of their hygroscopicity and/or chemical composition has been rather scarce (Pikridas et al., 2010). To the best of our knowledge, only Stock et al. (2011) have carried out measurements using a hygroscopic tandem differential mobility analyser (HTDMA) system at Finokalia on the island of Crete. During that study the observed hygroscopic growth factors of particles having dry mobility diameters of 50,80 and $150 \mathrm{~nm}$ ranged from 1.12 to 1.59 when exposed at $90 \%$ relative humidity.

In this work we report high temporal resolution chemical composition and hygroscopicity measurements of particles in the atmosphere over the Aegean Sea. Chemical composition measurements of non-refractory fine aerosol particles were conducted using an airborne compact time-of-flight aerosol mass spectrometer (cToF-AMS) onboard the UK BAe-146-301 Atmospheric Research Aircraft, which was operated through the Facility for Airborne Atmospheric Measurement (referred to as the FAAM BAe-146 aircraft from this point onwards). Particle hygroscopicity measurements were performed by an HTDMA system located on the island of Lemnos in the northern region of the Aegean Sea. Good closure between cToF-AMS and HTDMA measurements (agreement within $\pm 5 \%$ uncertainty) was achieved when the aircraft flew in the vicinity of the ground station. Using the parameterisation from the closure study, we employ the cToF-AMS measurements to determine vertical profiles of the hygroscopic parameter $\kappa_{\text {mix }}$ of the particles in the region.

\section{Methods}

A combination of airborne chemical composition and ground-based hygroscopicity measurements of aerosol particles over the Aegean Sea was performed from 25 August to 10 September 2011 . The equipment and the data analysis methods are briefly presented in the following paragraphs.

\subsection{Experimental}

\subsubsection{Airborne measurements}

The airborne measurements involved a total of three flights from Crete to Lemnos and back with the FAAM BAe146 aircraft (cf. Tombrou et al., 2012). The cToF-AMS was operational in only two of these flights; namely flights b637 and b641 performed on 1 and on 4 September, respectively. Detailed paths of these flights are shown in Fig. 1. In both cases the aircraft took off from Chania Airport, on Crete and headed east before turning north towards the island of Lemnos. The first flight took place from 09:00 to 13:45 UTC on 1 September. During that flight, the altitude of the aircraft was above $300 \mathrm{~m}$ on its way to Lemnos (eastern leg of the flight). To capture the vertical variation of the chemical composition of the particles along this path, the aircraft performed two missed approaches: one over the central Aegean Sea, and one over the island of Lemnos (Tombrou et al., 2012). The second flight took place from 11:13 to 15:38 UTC on 4 September. During that flight, the altitude of the aircraft along the leg from Crete to Lemnos (i.e. the part over the eastern Aegean Sea) was at lower altitude, almost constantly at $150 \mathrm{~m}$ above sea level (a.s.1.). The flight leg from Lemnos to Crete (i.e. the part over the western Aegean Sea) was in general at altitudes above $2.3 \mathrm{~km}$ during both flights, except for a small period during the second flight when the aircraft flew at $160 \mathrm{~m}$ a.s.l. on the southeast of Athens. Considering that the marine atmospheric boundary layer (MABL) was below $1 \mathrm{~km}$, some parts of the flights were within and some above it.

The non-refractory submicron chemical composition of the aerosol particles was determined by a cToF type (Canagaratna et al., 2007; Drewnick et al., 2005) AMS (Aerodyne Research Inc.) onboard the aircraft. Details of the airborne cToF-AMS instrument and the algorithm used for the analysis of the measurements are provided in Morgan et al. (2010). In brief, air was sampled through a Rosemount inlet 


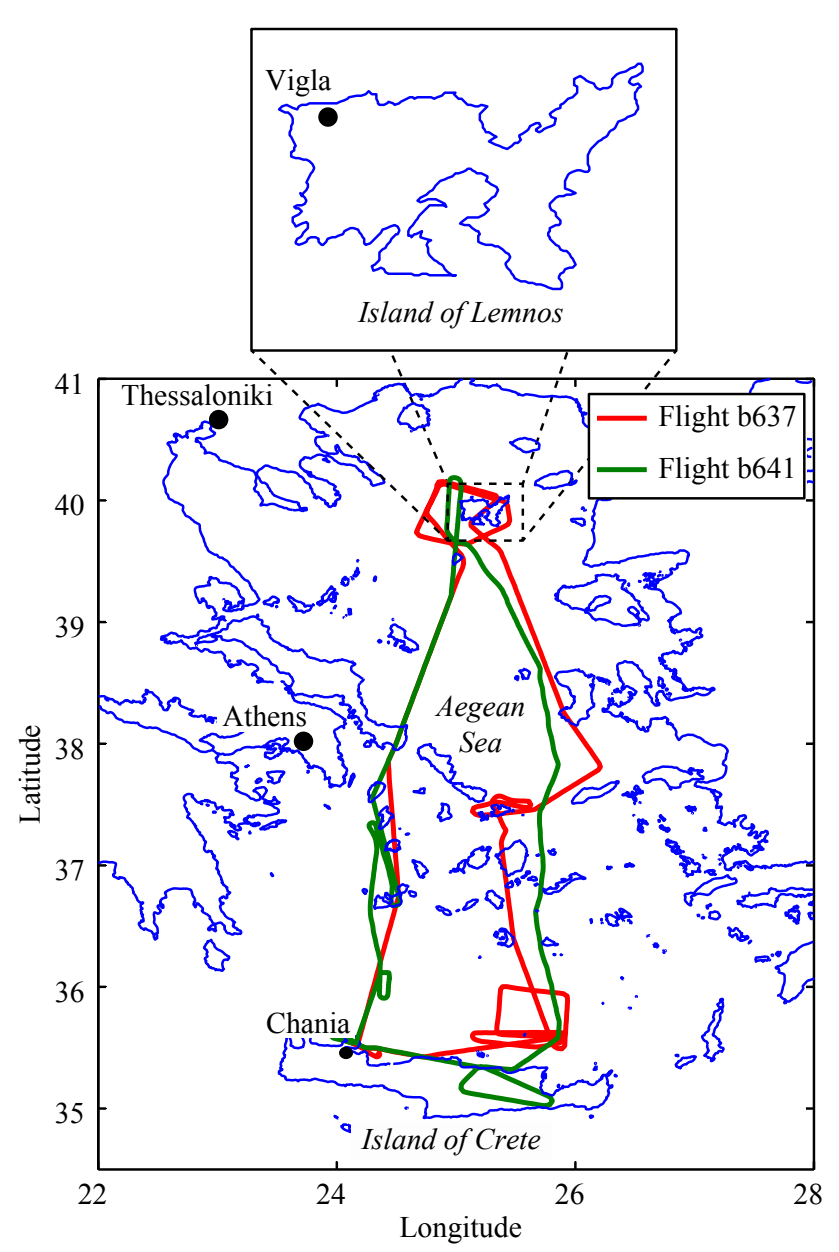

Fig. 1. Map of Greece showing the island of Lemnos and the location of the ground station at Vigla on the northwestern part of the island. The red and green lines show the paths followed by the FAAM BAe-146 aircraft on flights b637 and b641, performed on 1 and 4 September, respectively.

(a forward-facing, sub-isokinetic inlet with sampling efficiency close to unity for particles $\leq 600 \mathrm{~nm}$; for more details cf. Foltescu et al., 1995), mounted on the aircraft fuselage. Inside the AMS an aerodynamic lens (Wang et al., 2005) was used for focusing the sampled particles onto the heated surface, which was maintained at $600{ }^{\circ} \mathrm{C}$. The vapours resulting from volatilising the particles on the heated surface were then ionised using electron impact at $70 \mathrm{eV}$, and the ion fragments were analysed by a quadruple mass spectrometer for specific ions, including $\mathrm{NH}_{4}^{+}, \mathrm{Cl}^{-}, \mathrm{NO}_{3}^{-}, \mathrm{SO}_{4}^{2-}$ and organics. The cToF-AMS can measure particles having vacuum aerodynamic diameters (VADs) in the range from 50 to $700 \mathrm{~nm}$ (Liu et al., 2007), with a detection limit of ca. $50 \mathrm{ng} \mathrm{m}^{-3}$.

The cToF-AMS was calibrated using monodisperse ammonium nitrate particles and the recorded measurements were analysed using the fragmentation table approach (Allan et al., 2003, 2004) with the modifications introduced by Aiken et al. (2008). Corrections for variations in the composition-dependent collection efficiency were applied according to the parameterisation introduced by Middlebrook et al. (2012).

\subsubsection{Ground measurements}

The ground-based hygroscopicity measurements were conducted at a station located $420 \mathrm{~m}$ a.s.l. in the area of Vigla, on the northwestern part of the island of Lemnos $\left(39^{\circ} 58^{\prime} \mathrm{N}\right.$, $25^{\circ} 04^{\prime} \mathrm{E}$; cf. Fig. 1). The area is far from any major city and from local anthropogenic sources. A custom-made HTDMA system (Rader and McMurry, 1986) and a commercially available scanning mobility particle sizer (SMPS, TSI Model 3034; Wang and Flagan, 1990) were used to measure the hygroscopic growth factor and the size distribution of the particles, respectively. For these measurements, ambient air was sampled through a $6-\mathrm{m}$ long copper tube (ID $=26 \mathrm{~mm}$ ) with a total flow rate of $30.0 \mathrm{lpm}$ at atmospheric conditions. From this flow, $0.3 \mathrm{lpm}$ were sampled by the HTDMA system and $1.0 \mathrm{lpm}$ by the SMPS. A silica-gel diffusion drier was used upstream of the two systems in order to maintain the relative humidity $(\mathrm{RH})$ of the sampled flow at $30 \pm 3 \%$. The SMPS system measured the particle size distribution from 10 to $487 \mathrm{~nm}$, whereas the HTDMA measured the hygroscopicity of the particles having dry diameters from 50 to $170 \mathrm{~nm}$.

The HTDMA system consisted of two differential mobility analysers (DMAs; Knutson and Whitby, 1975), and a condensation particle counter (CPC, TSI Model 3022A; Stolzenburg and McMurry, 1991). The first DMA (DMA-1, TSI 3080) included a ${ }^{85} \mathrm{Kr}$ aerosol neutraliser and a closed-loop system for recirculating the sheath flow. The second DMA (DMA-2) employed a custom-made system for the sheath flow recirculation with an RH controller (cf. Biskos et al., 2006a). For each measurement, the voltage on DMA-1 was adjusted to select dry aerosol particles having mobility diameters from 50 to $170 \mathrm{~nm}$. The quasi-monodisperse particles downstream of DMA-1 were conditioned within a single Nafion-tube humidity exchanger (Perma Pure Model MD$110)$ to a constant RH of $85 \%$. The size distribution of the humidified particles was then measured by DMA- 2 and the CPC. The aerosol and the sheath flows for both DMAs were 0.3 and $3.0 \mathrm{lpm}$, respectively.

The RH and temperature of the aerosol flow downstream the humidity exchanger and of the sheath flow in DMA-2 were measured by two humidity/temperature sensors (Rotronic Model SC-05). A proportional-integral-derivative (PID) controller was used to control the RH in both flows by adjusting the flow of a parallel stream of very high $\mathrm{RH}$ (ca. $100 \%$ ) on the outer annulus of each Nafion-tube humidity exchanger. The overall performance of the HTDMA was tested with ammonium sulfate and sodium chloride particles produced by atomisation. The uncertainty of the particle size measurements by the system was less than $1 \%$ whereas $\mathrm{RH}$ variations were within less than $2 \%$ of the set point. 


\subsection{Data analysis}

\subsubsection{SMPS measurements}

The inversion of the SMPS measurements was performed using the Aerosol Instrument Manager software (AIM, TSI version 6.0), including correction for multiply charged particles. The inverted particle-number size distributions were then analysed using a curve-fitting algorithm similar to that described in Hussein et al. (2005). This algorithm employed the least squares method to fit the sum of up to three lognormal distributions to the measurements. The first lognormal distribution corresponded to particles having a geometric mean mobility diameter from 10.0 to $25.0 \mathrm{~nm}$ (nucleation mode), the second from 25.1 to $90.0 \mathrm{~nm}$ (Aitken mode), and third from 90.1 to $500.0 \mathrm{~nm}$ (accumulation mode). The geometric standard deviation of each lognormal distribution was allowed to vary between 1.2 and 2.1. The algorithm starts by fitting a tri-modal lognormal distribution to the measurements, and successively tests the possibility of reducing it to a bi- or to a uni-modal distribution based on the estimated particle-number concentration of each mode, the geometric mean diameter, and the geometric standard deviation of the neighbouring modes.

\subsubsection{HTDMA measurements}

The hygroscopic growth factor, $g$, determined by the HTDMA measurements is given by

$g(\mathrm{RH})=\frac{d_{\mathrm{m}}(\mathrm{RH})}{d_{m, \mathrm{dry}}}$,

where $d_{\mathrm{m}}(\mathrm{RH})$ and $d_{m, \text { dry }}$ are the geometric mean mobility diameters of the sampled particles at the hydrated state (i.e. $\mathrm{RH}=85 \%$ ) measured by DMA-2 and the CPC, and at the dry state, i.e. the mobility diameter selected by DMA-1, respectively. The RH at the inlet of DMA-1 varied between 27 and $33 \%$, having an average value of $30 \%$ during the entire period of the measurements. As a result, the measured growth factor can be more accurately expressed as

$g(85 \% \mid 30 \%)=\frac{d_{\mathrm{m}}(85 \%)}{d_{\mathrm{m}}(30 \%)}$.

Here $d_{\mathrm{m}}(30 \%)$ is the nominal mobility diameter of the particles selected by DMA- 1 , and $d_{\mathrm{m}}(85 \%)$ is the mobility diameter measured by DMA-2 and the CPC of the HTDMA system.

Internally mixed monodisperse particles of uniform chemical composition will grow to the same size when subjected to identical RH conditions downstream of DMA-1. Externally mixed particles, on the other hand, can grow to sizes that may or may not be distinguishable in the HTDMA scans. In this case, the size distribution of the humidified monodisperse particles can exhibit a single mode that is significantly broadened compared to that of the dry sample, or distinct monodisperse modes, depending on the hygroscopic variability of the particles.

To distinguish between modes that may correspond to different particle populations in a systematic way, we employed the TDMAfit algorithm (Stolzenburg and McMurry, 1988) for inverting the HTDMA measurements. The algorithm uses the least squares method to fit Gaussian-shaped transfer functions to the measured response of the system. To locate the peak positions and the associated particle-number concentrations that give the best fit, the algorithm employs a search routine that is based on a number of convergence criteria and constraints. When a chi-square function of the fit residual changes by less than $0.1 \%$ and each of the fitted parameters alters by less than $10 \%$ of its respective estimated uncertainty, the TDMAfit algorithm is considered to have converged to the best fit. Measurements inverted also by the TDMAinv algorithm developed by Gysel et al. (2009) gave hygroscopic growth factors that agreed within less than $\pm 2.5 \%$ with those calculated by TDMAfit.

For the analysis of the HTDMA measurements, we assumed that all the particles have a spherical shape when selected by DMA-1, and that particle shrinkage due to the presence of volatile species (e.g. ammonium nitrate) was negligible. Under these assumptions, measured hygroscopic growth factors less than 1.0, comprising ca. $3 \%$ of all the measurements, were excluded.

\subsubsection{Determining hygroscopic growth factors from the AMS measurements}

The hygroscopic growth factor of internally mixed particles, $g_{\text {mix }}$, can be estimated using the AMS measurements as (Kreidenweis et al., 2008)

$g_{\text {mix }}(\mathrm{RH})=\left(1+\kappa_{\text {mix }}\left(\frac{\alpha_{\mathrm{w}}}{1-\alpha_{\mathrm{w}}}\right)\right)^{\frac{1}{3}}$,

where $\alpha_{\mathrm{W}}$ is the water activity of the solution droplet, which neglecting the Kelvin effect is equal to RH/100, and $\kappa_{\text {mix }}$ is the hygroscopic parameter of the mixed particles given by

$\kappa_{\text {mix }}=\sum_{\mathrm{i}} \epsilon_{\mathrm{i}} \kappa_{\mathrm{i}}$.

Here $\epsilon_{\mathrm{i}}=V_{\mathrm{si}} / V_{\mathrm{s}}$ and $\kappa_{\mathrm{i}}$ are the volume fraction and the hygroscopic parameter of the ith chemical species of the particles, with $V_{\mathrm{si}}$ being the volume occupied by that species and $V_{\mathrm{s}}$ the dry volume of the particle.

To estimate the volume fractions of each species of the particles from the cToF-AMS mass measurements, we first determined the molar fractions of the ions and then those of the chemical compounds comprising the particles using the ion pairing algorithm proposed by Pilinis et al. (1987), and later simplified by Gysel et al. (2007). In this simplified algorithm, by setting the fraction of nitric acid to zero, the molar fraction of ammonium nitrate is equal to the molar fraction of nitrate ions. The rest of the ammonium ions are assigned to the 
Table 1. Hygroscopic parameters $\kappa$ and densities $\rho$ used in the $\kappa$ Köhler theory (Eq. 3).

\begin{tabular}{lcc}
\hline Chemical species & $\kappa$ & $\rho\left(\mathrm{kg} \mathrm{m}^{-3}\right)$ \\
\hline$\left(\mathrm{NH}_{4}\right)_{2} \mathrm{SO}_{4}$ & $0.53^{\mathrm{a}}$ & $1769^{\mathrm{b}}$ \\
$\mathrm{NH}_{4} \mathrm{HSO}_{4}$ & $0.56^{\mathrm{a}}$ & $1720^{\mathrm{b}}$ \\
$\mathrm{NH}_{4} \mathrm{NO}_{3}$ & $0.68^{\mathrm{a}}$ & $1780^{\mathrm{b}}$ \\
$\mathrm{H}_{2} \mathrm{SO}_{4}$ & $0.97^{\mathrm{d}}$ & $1830^{\mathrm{b}}$ \\
Organics & $0.00-0.20^{\mathrm{b}}$ & $1200-1700^{\mathrm{c}}$ \\
\hline
\end{tabular}

a Petters and Kreidenweis (2007);

b Duplissy et al. (2011);

${ }^{c}$ Hallquist et al. (2009);

d Biskos et al. (2009).

sulfate ions, and depending on the ammonium to sulfate ratio, the molar fractions of sulfuric acid, ammonium bisulfate and ammonium sulfate are determined. To convert the mole fractions to volume fractions, we used the bulk densities for every chemical species as summarised in Table 1 (Duplissy et al., 2011). The respective hygroscopic parameters are also shown in Table 1 (Petters and Kreidenweis, 2007; Biskos et al., 2009). For the organic compounds commonly present in atmospheric particles, the density, $\rho_{\text {org }}$, and hygroscopic parameter, $\kappa_{\text {org }}$, can vary from 1200 to $1700 \mathrm{~kg} \mathrm{~m}^{-3}$ (Hallquist et al., 2009), and from 0.0 to 0.2 (Petters and Kreidenweis, 2007), respectively.

\section{Results and discussion}

The prevailing synoptic conditions during the entire period of the measurements correspond mainly to north easterlies surface winds over the Aegean Sea, being associated with a large-scale surface anticyclone. From 30 August to 3 September, however, the wind speeds were substantially lower with northwesterly directions. In particular, during the flight performed on 1 September (flight b637), a large-scale surface anticyclone prevailed over southeastern Europe, producing fair weather conditions and a moderate flow from the north-east sector over the Aegean Sea. During the flight performed on 4 September (flight b641), the low pressure pattern that prevailed over southeastern Europe, in combination with the anticyclone over Balkans, resulted in a strong channelled surface-wind flow over the Aegean Sea. Average wind speeds of up to $20 \mathrm{~m} \mathrm{~s}^{-1}$ were measured at altitudes $150 \mathrm{~m}$ a.s.l, but diminished above $4.5 \mathrm{~km}$. When the aircraft flew in the vicinity of the station on Lemnos, the surface winds were from southwest direction and lower than $5 \mathrm{~m} \mathrm{~s}^{-1}$ during the first flight, and from northeast directions with speeds ranging from 9.5 to $13 \mathrm{~m} \mathrm{~s}^{-1}$ during the second flight. The surface temperature and $\mathrm{RH}$ at the ground station on Lemnos during the two missed approaches were 28 and $21{ }^{\circ} \mathrm{C}$, and 45 and $75 \%$, respectively. For the entire period of the measurements, the surface temperature and the $\mathrm{RH}$ at the ground station ranged from 17.7 to $29.6^{\circ} \mathrm{C}$ and from 16 to $87 \%$, respectively.

\subsection{Measurements in the atmosphere over the ground station}

As described in Sect. 2.1, the size distributions and the hygroscopicities of the particles were continuously measured at the ground station during the entire period of the campaign. During each flight, the FAAM BAe146 aircraft flew in the vicinity of the ground station (i.e. $\pm 300 \mathrm{~m}$ above or below the station and within a radius of $30 \mathrm{~km}$ ) for approximately 10 to $15 \mathrm{~min}$. The measurements performed by the airborne cToF-AMS during these two time windows were used to check the closure between hygroscopicity and chemical composition measurements. The following paragraphs provide an overview of the ground-based measurements and the closure study.

\subsubsection{Particle size distributions}

The evolution of the $1 \mathrm{~h}$ averaged particle size distributions measured by the SMPS, together with time series of the number concentration of particles having dry mobility diameter in the ranges of $50-80,80-100$ and $100-170 \mathrm{~nm}$, for all the days of the experiment are shown in Fig. 2. The total number concentration of the particles having diameters from 10 to $487 \mathrm{~nm}$ varied from ca. $4.4 \times 10^{2}$ to $1.0 \times 10^{4}$ particles $\mathrm{cm}^{-3}$, with median value of $1.9 \times 10^{3}$. Almost $72.1 \%$ of the samples exhibited bi-modal distributions, whereas $14.2 \%$ and $13.7 \%$ of them showed uni-modal and tri-modal distributions, respectively. The total particle number concentration in the nucleation mode varied from $1.7 \times 10^{2}$ to $3.2 \times$ $10^{3}$ particles $\mathrm{cm}^{-3}$, with a median value of $7.7 \times 10^{2}$, in the Aitken mode from $1.7 \times 10^{2}$ to $7.1 \times 10^{3}$ particles $\mathrm{cm}^{-3}$, with a median value of $1.0 \times 10^{3}$, and in the accumulation mode from $1.8 \times 10^{2}$ to $3.4 \times 10^{3}$ particles $\mathrm{cm}^{-3}$, with a median value of $9.0 \times 10^{2}$. Most often the particles were observed in the Aitken and the accumulation modes during the entire period of the measurements. Particle size distribution measurements over the region of the Aegean Sea are only available for the station of Finokalia on Crete (Pikridas et al., 2010). According to that study, the average total number concentration of particles having mobility diameters from 10 to $500 \mathrm{~nm}$ was ca. $2.7 \times 10^{3}$ particles $\mathrm{cm}^{-3}$, which is very similar to the concentrations measured on Lemnos.

From 30 August to 3 September, the majority of the particles resided in the accumulation and the Aitken modes. The rest of the period was characterised by wider size distributions with particles residing also in the nucleation mode (i.e. particles having diameter smaller than $25 \mathrm{~nm}$ ). This pattern is well correlated with the variability in the origin of the air masses arriving at the station (cf. discussion in Sect. 3.2 and back-trajectory calculations shown in Fig. S1). 


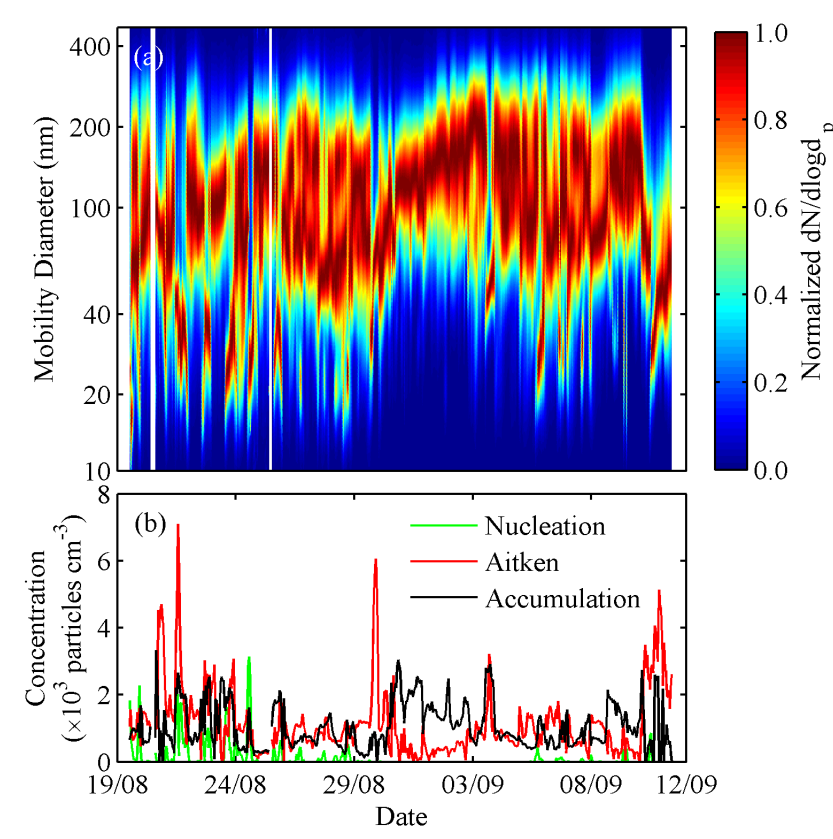

Fig. 2. Evolution of normalised, hourly averaged size distributions of particles having dry mobility diameters from 10 to $487 \mathrm{~nm}$ (a), and temporal variation of the respective number concentration of particles residing in the nucleation, Aitken and accumulation modes (b) throughout the whole period of the Aegean-Game field campaign.

\subsubsection{Particle hygroscopicity}

Characteristic raw measurements by the ground-based HTDMA are shown in Fig. 3. The recorded size distributions correspond to particles having dry mobility diameters (i.e. diameters selected by DMA-1) of 70, 90, and $150 \mathrm{~nm}$ after being exposed to $85 \% \mathrm{RH}$. The respective hygroscopic growth factors $g(85 \% \mid 30 \%)$ of those samples are $1.22,1.22$, and 1.21. In almost all the HTDMA measurements, the geometric standard deviation of the size distribution of the humidified particles was similar to that of the dry ones, indicating that the samples were internally mixed. This is expected in remote areas with no major local anthropogenic particle sources.

Figure 4 shows the hygroscopic growth factors $g(85 \% \mid 30 \%)$ measured by the HTDMA (Fig. 4a) together with the measured (SMPS data) number concentrations of the particles having dry diameters in the ranges selected by DMA-1 (Fig. 4b) during the entire period of the campaign. The measurements are grouped in three different classes, depending on the dry mobility diameters selected by DMA1: green circles and curve correspond to measurements of particles having dry mobility diameters from 50 to $80 \mathrm{~nm}$, red squares and curve from 80 to $100 \mathrm{~nm}$, and blue diamonds and curve from 100 to $170 \mathrm{~nm}$. Note that although the dry diameter was selected to be close to the peak of the most dominant mode of the particle size distribution as measured

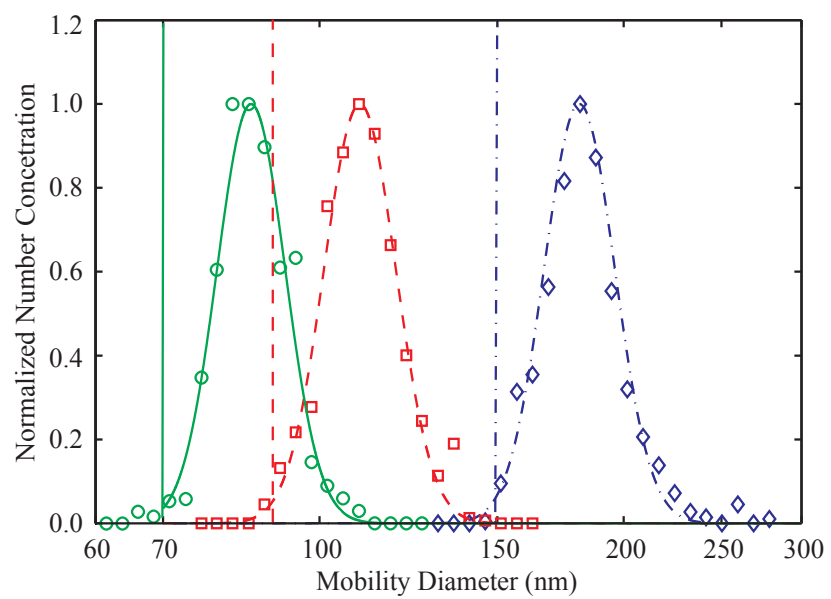

Fig. 3. Size distribution measurements of the humidified monodisperse particle samples recorded by the HTDMA system. Particles having dry mobility diameters of 70 (green), 90 (red), and $150 \mathrm{~nm}$ (blue) selected by DMA-1 at $30 \pm 3 \% \mathrm{RH}$ were exposed to $85 \%$ $\mathrm{RH}$ and measured by DMA-2 and the CPC. Symbols represent the actual measurements and lines the fitted curves determined by the TDMAFIT algorithm. One hygroscopic mode is observed in all the measurements, corresponding to growth factors of 1.22, 1.22 and 1.21 , for the 70-, 90- and 150-nm dry particles, respectively.

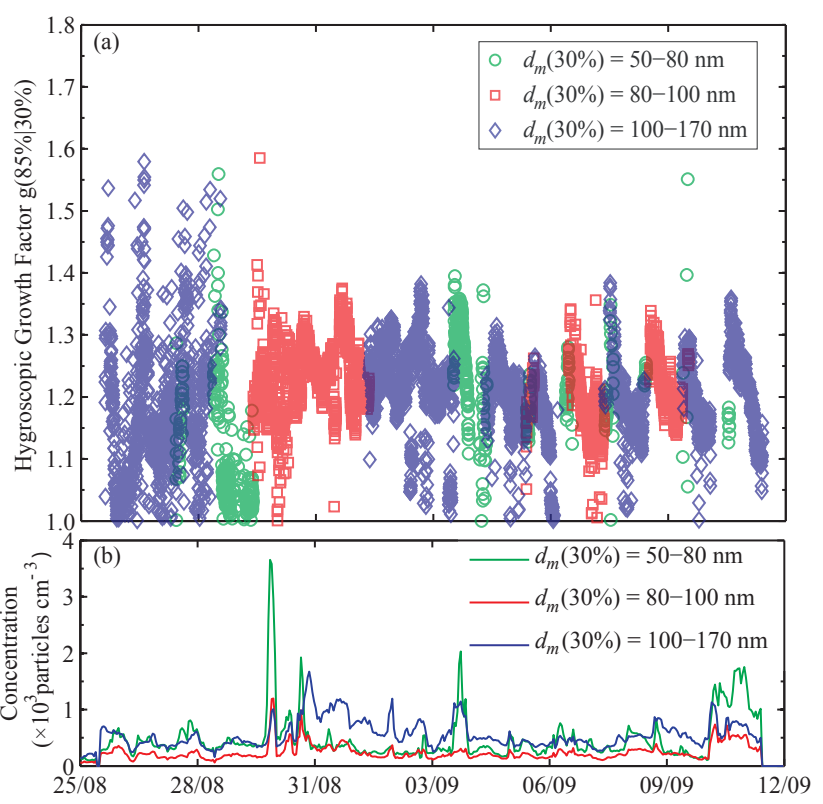

Fig. 4. Time series of the hygroscopic growth factors of atmospheric aerosol particles measured with the HTDMA (a) and number concentrations of the particles having dry mobility diameters in the ranges sampled by the HTDMA (b) at the ground station on Lemnos Island. Aerosol particles are grouped in three different regions based on their dry mobility diameters: from 50 to $80 \mathrm{~nm}$ (green circles and curve), from 80 to $100 \mathrm{~nm}$ (red squares and curve), and from 100 to $170 \mathrm{~nm}$ (blue diamonds and curve). 
by the SMPS, measurements of dry particles in other modes were randomly sampled to investigate potential differences in their hygroscopicity. For the Aitken (19\% of the samples) and accumulation ( $81 \%$ of the samples) mode particles, the average growth factors were 1.18 (ranging from 1.00 to 1.56 ) and 1.21 (ranging from 1.00 to 1.59 ), respectively. The average growth factor for all particle sizes was 1.20 , having a minimum value of 1.00 and a maximum of 1.59 . Periods with particles of high (from 25 to 30 August), low (from 30 August to 2 September) and moderate (from 2 to 9 September) variation in the growth factor can be identified in the HTDMA measurements. This difference is well correlated with the variability in the origin of the air masses arriving at the station. During the days with the low variation in particle hygroscopicity, the air masses reaching the station had almost the same origin (i.e. the Black Sea), as indicated in Fig. S1 in the Supplement.

Although the selected dry diameters correspond to different periods during the campaign, they exhibit very similar growth factors when comparing nearby measurements. Considering also that the variability and the average growth factors corresponding to particles having different dry diameters are also very similar, in most of the cases, suggests that there is no noticeable variation of chemical composition as a function of particles size. It should also be pointed out that the selected dry particles had diameters in the range from 50 to $170 \mathrm{~nm}$, within which the contribution of the Kelvin effect to the hygroscopic growth of the particles is negligible (Biskos et al., 2006b; Park et al., 2009).

The average hygroscopic growth factor measured in our work is ca. $12 \%$ lower compared to those reported by Stock et al. (2011), who also employed an HTDMA system at Finokalia, on the island of Crete, from 12 August to 20 October 2005. The hygroscopic growth factors of particles having dry diameters 50, 80, and $150 \mathrm{~nm}$ observed during that study ranged from 1.12 (nearly hydrophobic particles) to 1.59 (more hygroscopic particles). Considering that those HTDMA measurements were conducted at $90 \% \mathrm{RH}$ using the $\kappa$-Köhler theory (i.e. Eqs. 3 and 4), we calculate the corresponding growth factors at $85 \% \mathrm{RH}$ to be in the range from 1.08 to 1.43 . Although this range is similar to that observed in our study, the occurrence frequency of the more hygroscopic particles reported by Stock et al. (2011) was significantly higher (of the order of 84 to $90 \%$ ) compared to that in our study (i.e. ca. $35 \%$ ).

\subsubsection{Particle chemical composition and hygroscopicity}

Figure 5 shows the chemical composition of the atmospheric particles when the aircraft was flying within a $30 \mathrm{~km}$ radius from the ground station and between 100 and $700 \mathrm{~m}$ altitude (i.e. ca. $\pm 300 \mathrm{~m}$ from the altitude of the ground station). The reported volume fractions are estimated by applying the ion pairing algorithm to the cToF-AMS measurements (cf. Sect. 2.2.3). The organic species comprised almost $50 \%$ of
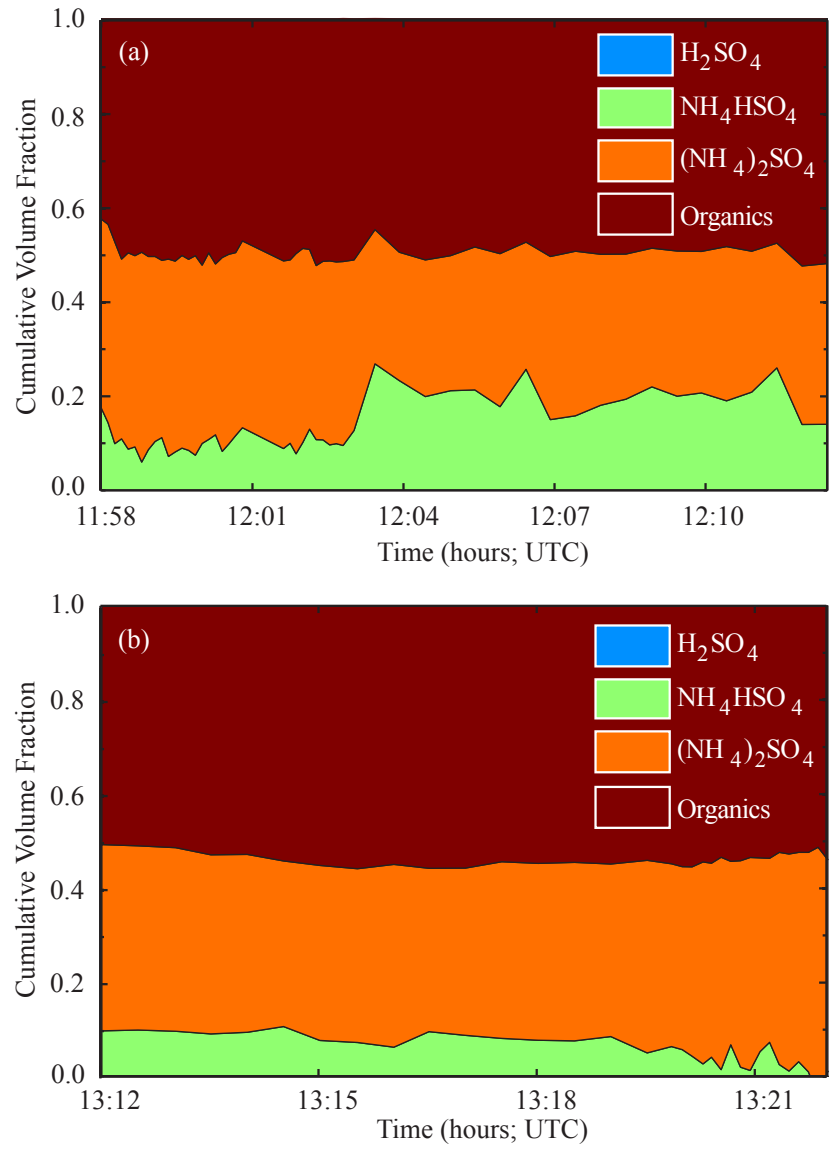

Fig. 5. Cumulative volume fractions of the chemical species comprising the particles in the atmosphere over the ground station on Lemnos Island during the flights performed on 1 September (flight b637) (a) and on 4 September (flight b641) (b). The volume fractions are estimated by the ion pairing algorithm and the chemical composition measurements from the airborne cToF-AMS.

the total particle dry volume, whereas ammonium sulfate and ammonium bisulfate accounted for the rest. Although the volume fraction of the organic species was similar during both days, the inorganic fraction of the particles was more acidic during the flight on 1 September (Fig. 5a). Considering that during both flights the chemical composition of the particles did not show high variability with size (data not shown), the cToF-AMS measurements can be considered as representative for the entire particle size range and therefore can be used to predict the hygroscopic growth of the particles using the $\kappa$-Köhler theory.

The comparison between predicted (i.e. using Eqs. (3) and (4) and the cToF-AMS measurements) and measured (i.e. using Eq. (2) and the HTDMA measurements) hygroscopic growth factors is shown in Fig. 6. The particles measured by the HTDMA had dry mobility diameters of $100 \mathrm{~nm}$. To account for the fact that the relative humidity of the dry sample was $30 \%$, and therefore the particles entering the HTDMA may have already had some water due to their acidity 

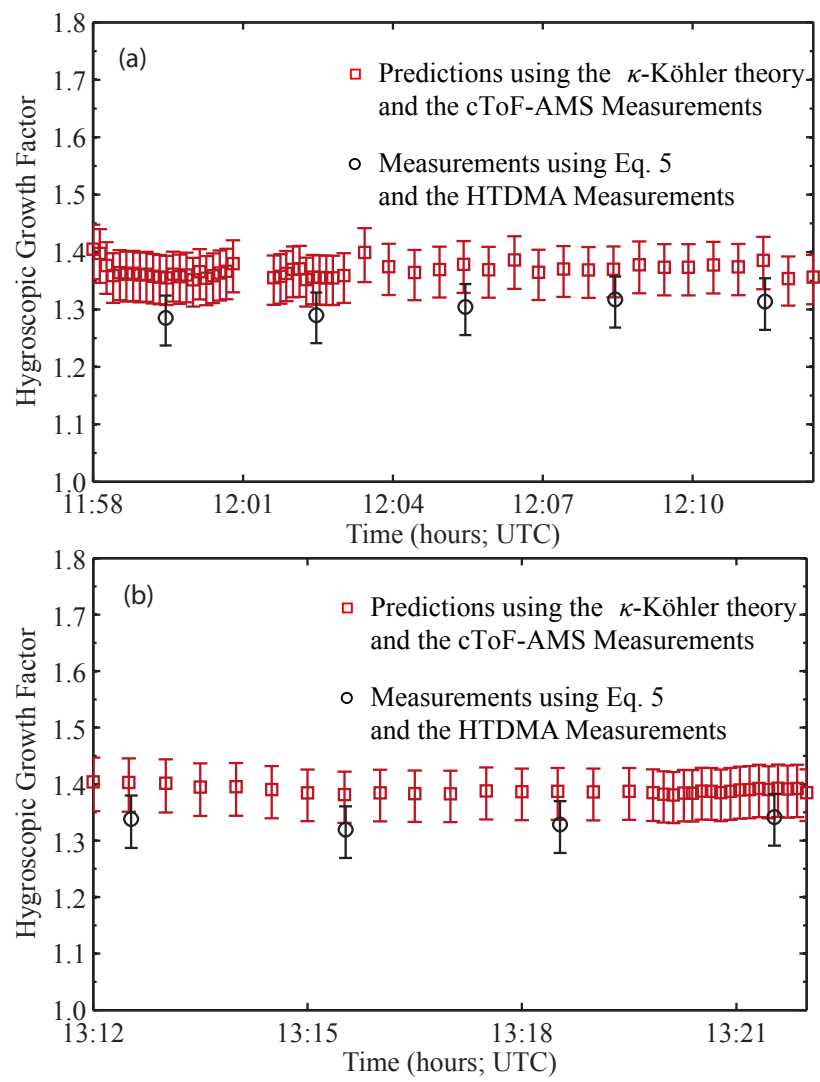

Fig. 6. Hygroscopic growth factors measured by the HTDMA (black dots) and predicted by $\kappa$-Köhler theory using the chemical composition measurements from the airborne cToF-AMS (red squares) when the aircraft was flying close to Vigla station on 1 (flight b637) September 2011 (a) and on 4 (flight b641) (b) September 2011. The HTDMA growth factors correspond to particles having dry mobility diameter of $100 \mathrm{~nm}$, whereas the chemical composition corresponds to particles having Vacuum Aerodynamic Diameters (VADs) in the range 50-700 $\mathrm{nm}$. Error bars represent the $2 \%$ uncertainty in the RH measurements.

(cf. Biskos et al., 2009; Engelhart et al., 2011) and/or their organic content (cf. Marcolli et al., 2004), we calculate the absolute growth factor at $85 \% \mathrm{RH}$ as

$g(85 \%)=\frac{d_{\mathrm{m}}(85 \%)}{d_{\mathrm{m}, \mathrm{dry}}}=\frac{d_{\mathrm{m}}(30 \%)}{d_{\mathrm{m}, \mathrm{dry}}} \times \frac{d_{\mathrm{m}}(85 \%)}{d_{\mathrm{m}}(30 \%)}$

$=g(30 \%) \times g(85 \% \mid 30 \%)$.

Here $g(85 \% \mid 30 \%)$ is the measured growth factor (cf. Eq. 2) and $g(30 \%)$ is the growth factor of the particles entering the HTDMA at $30 \% \mathrm{RH}$. The latter is estimated using the $\kappa$ Köhler theory and the composition measurements provided by the cToF-AMS. The estimated $g(30 \%)$ values varied from 1.03 to 1.06 during the specific measurements.

For the predicted growth factors shown in Fig. 6, we used the fixed $\kappa$ and $\rho$ values for the inorganic species shown in Table 1 . The values of $\kappa_{\text {org }}$ and $\rho_{\text {org }}$ were determined as follows. By keeping $\kappa_{\text {org }}=1200 \mathrm{~kg} \mathrm{~m}^{-3}$ (i.e. the lowest density of organic species as indicated from the literature; cf. Hallquist et al., 2009), we increased $\kappa_{\text {org }}$ from 0 up to the value that the predicted hygroscopic growth factors agreed with the measured ones within $5 \%$. In a similar manner, we increased $\rho_{\text {org }}$ from $1200 \mathrm{~kg} \mathrm{~m}^{-3}$ by keeping $\kappa_{\text {org }}=0$. From the resulting ranges of $\kappa_{\text {org }}$ and $\rho_{\text {org }}$, we used the mean values as the most representative for each day. Following this procedure we estimated $\kappa_{\text {org }}=0.03$ and $\rho_{\text {org }}=1300 \mathrm{~kg} \mathrm{~m}^{-3}$ during the flight on 1 September, and $\kappa_{\text {org }}=0.1$ and $\rho_{\text {org }}=1400 \mathrm{~kg} \mathrm{~m}^{-3}$ during the flight on 4 September. Evidently, the organic fraction of the particles observed during the closure on 4 September was more hygroscopic and slightly more dense compared to that on 1 September. In either case, the organic fraction of the particles was far less hygroscopic than the inorganic fraction, resulting in a reduction of the amount of water they could uptake as compared to their pure inorganic counterparts.

\subsection{Measurements in the atmosphere over the Aegean Sea}

In the paragraphs that follow we provide an overview of the cToF-AMS chemical composition measurements conducted over the Aegean Sea during the two flights of the campaign, and employ them to predict the representative hygroscopic parameter of the particles using the $\kappa$-Köhler theory.

\subsubsection{Particle chemical composition}

The volume fractions of the compounds comprising the particles observed during the entire flights on 1 and 4 September are shown in Figs. 7 and 8, respectively. During the flight on 1 September (data shown in Fig. 7), the volume fraction of sulfuric acid, ammonium bisulfate, and ammonium sulfate ranged from zero to 0.86 , with a median value of zero; from zero to 0.66 , with a median value of 0.22 ; and from zero to 1.00 , with a median value of 0.31 ; respectively. In two of the four vertical paths of the flight (i.e. above the central Aegean Sea and above the island of Lemnos), the acidity of the particles appeared to increase with increasing height, indicating that the concentration of ammonia was very low at high altitudes, as had been observed in other regions (e.g. Spengler et al., 1990). The volume fraction of ammonium sulfate was almost zero at lower altitudes, rising to 0.5 at $2.5 \mathrm{~km}$ a.s.l. This pattern was inverted in the two vertical paths above Crete. The volume fractions of ammonium bisulfate in this case were high at lower altitudes $(<700 \mathrm{~m}$ a.s.l. $)$ and, with the exception of a couple of points (one around 2.0 and one $3.7 \mathrm{~km}$ a.s.l.), decreased with increasing height. In all cases, the concentration of $\mathrm{H}_{2} \mathrm{SO}_{4}$ was almost zero for the entire flight, with the exception of a few measurements higher than $4.0 \mathrm{~km}$ a.s.l. over Crete.

As shown by back trajectory calculations (cf. Fig. S2), low-altitude air masses arriving over the north or central Aegean Sea originated from eastern Europe and the wider 

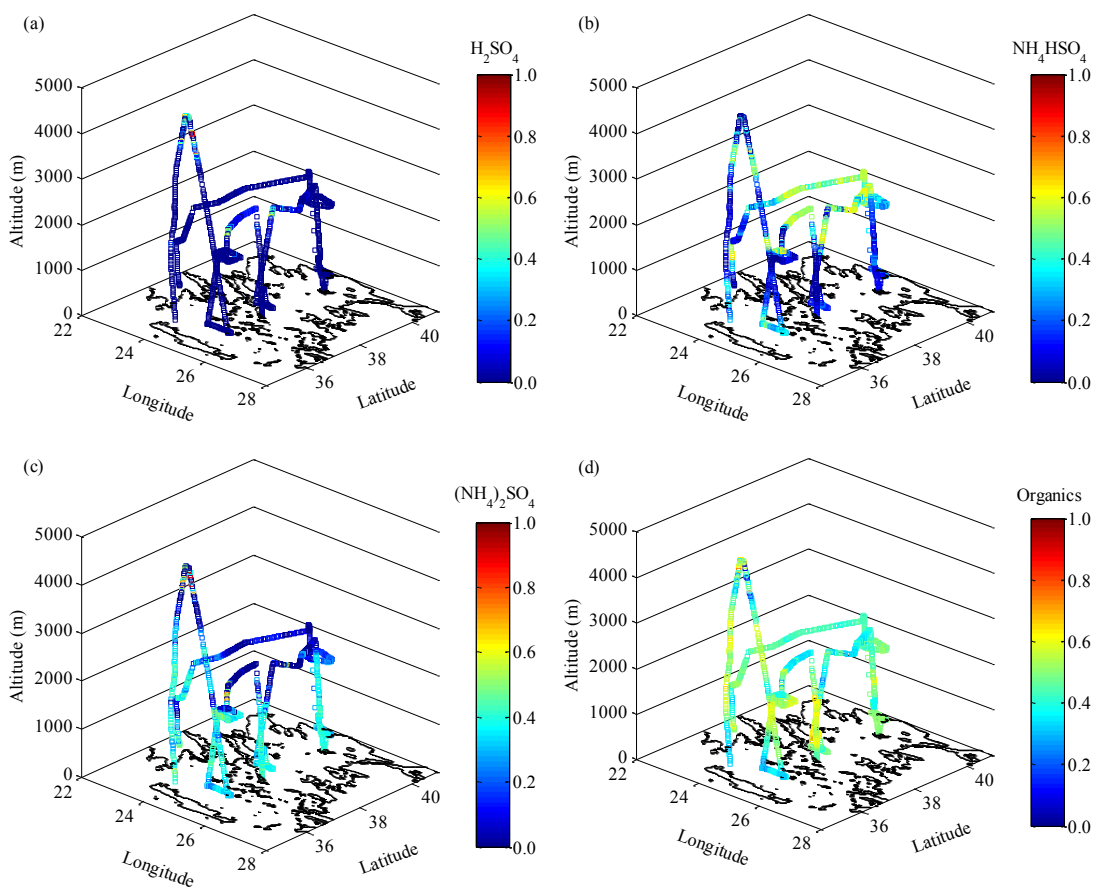

Fig. 7. Composition of the non-refractory compounds measured by the cToF-AMS during the flight performed on 1 September 2011 (flight b637) over the Aegean Sea. The reported volume fractions for $\mathrm{H}_{2} \mathrm{SO}_{4}(\mathbf{a}), \mathrm{NH}_{4} \mathrm{HSO}_{4}(\mathbf{b}),\left(\mathrm{NH}_{4}\right)_{2} \mathrm{SO}_{4}(\mathbf{c})$ and organic matter (d) are estimated using the mole fractions determined by the cToF-AMS measurements and the simplified ion pairing algorithm proposed by Gysel et al. (2007).
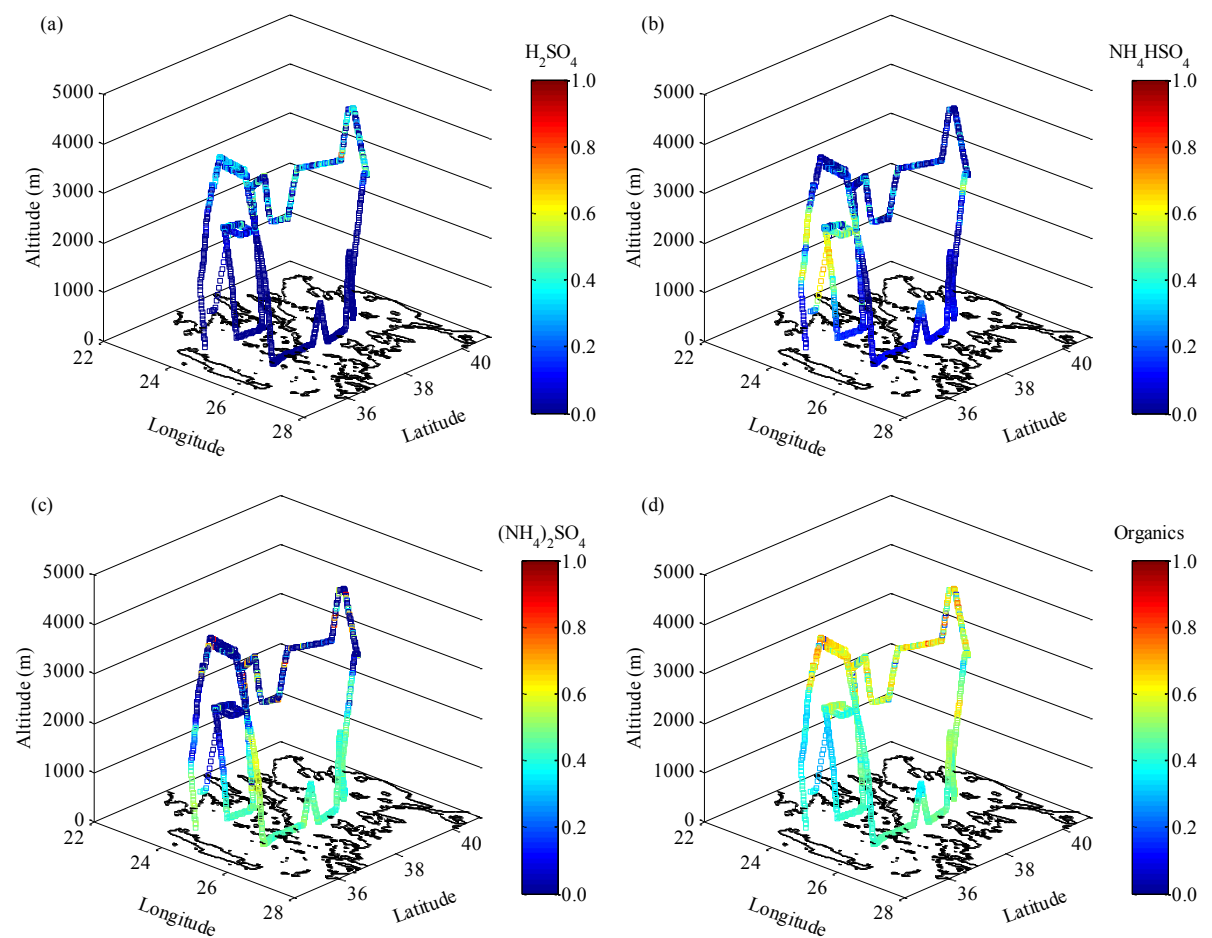

Fig. 8. Composition of the non-refractory compounds measured by the cToF-AMS during the flight performed on 4 September 2011 (flight b641) over the Aegean Sea. The reported volume fractions for $\mathrm{H}_{2} \mathrm{SO}_{4}$ (a), $\mathrm{NH}_{4} \mathrm{HSO}_{4}(\mathbf{b}),\left(\mathrm{NH}_{4}\right)_{2} \mathrm{SO}_{4}(\mathbf{c})$ and organic matter (d) are estimated using the mole fractions determined by the cToF-AMS measurements and the simplified ion pairing algorithm proposed by Gysel et al. (2007). 
Black Sea region. These air masses appeared to carry particles of very low acidity, as shown in Fig. 7. The low-altitude air masses arriving over Crete, on the other hand, originated either from the marine environment or from the mainland, but in both cases they passed over the wider Athens region. This can explain the high acidity of the particles observed at lower altitudes in that area. Acidic particles formed or directly emitted from anthropogenic activities in the region of Athens travelled over the central Aegean Sea towards Crete. The acidity of these particles did not change significantly during advection as a result of the low concentrations of ammonia over the marine environment (Clarisse et al., 2009). Acidic particles coming from eastern Europe (i.e. those arriving over the north Aegean Sea) have a greater chance of being neutralised due to the higher concentration of ammonia over the mainland.

The organic volume fraction of the particles observed during the flight conducted on 1 September ranged from zero to 0.74 , with a median value of 0.46 . Their vertical variability during all four vertical parts of the flight was similar, starting with low values at the lower altitudes, increasing at intermediated heights and decreasing again at even higher levels. The height of the layers with particles of high organic fractions differed from place to place, with the highest layer observed over the central Aegean Sea. Considering that the air masses arriving over Lemnos and the central Aegean Sea during the respective missed approaches have passed over urban, rural and marine environments, and that their origin was similar (i.e. from eastern Europe), the organic fraction of the particles could be either biogenic or anthropogenic.

The chemical composition of the particles observed during the flight on 4 September is shown in Fig. 8. During that flight the aircraft flew at lower altitudes from Crete to Lemnos (eastern leg of the flight) and at higher altitudes from Lemnos to Crete (western leg of the flight). Three of the four vertical parts of the flight in this case ended at substantially higher altitudes (ca. $4.0 \mathrm{~km}$ a.s.1.) compared to those of the first one. The vertical part of the flight over the central Aegean Sea was limited to ca. $1.0 \mathrm{~km}$. The volume fraction of sulfuric acid, ammonium bisulfate, and ammonium sulfate ranged from zero to 0.79 , with a median value of zero; from zero to 0.69 , with a median value of 0.10 ; and from zero to 0.97 , with a median value of 0.35 ; respectively. Similarly to the measurements recorded during the flight on 1 September, particle acidity increased with increasing altitude. In this case, however, the particles observed at ca. $2.5 \mathrm{~km}$ a.s.l. (i.e. similar to the altitude of the eastern leg of the first flight) were even more acidic, having a $\mathrm{H}_{2} \mathrm{SO}_{4}$ volume fraction that reached values as high as ca. 0.4. High volume fractions of $\mathrm{NH}_{4} \mathrm{HSO}_{4}$ were observed at a layer between 1.0 and $2.0 \mathrm{~km}$ a.s.l. over the west/northwest of Crete.

The respective fractions for the organic compounds of the particles during the flight conducted on 4 September ranged from 0.03 to 0.84 , with a median value of 0.48 . An increasing particle organic content is observed with increasing altitude, having median volume fractions of 0.44 and 0.54 for altitudes below and above $2.0 \mathrm{~km}$, respectively. Compared to the flight on 1 September, the vertical distributions of the second flight (i.e. 4 September) exhibited a higher uniformity. This can be explained by the fact that the air masses arriving in many regions over the study area all originated from central/western Europe and followed similar paths (cf. Fig. S3 in the Supplement).

\subsubsection{Particle hygroscopicity}

Using the bulk chemical composition measurements discussed above, we calculated vertical profiles of the aerosol hygroscopic parameter $\kappa_{\text {mix }}$ (Eq. 4) during the two flights (cf. Figs. 9 and 10). For these calculations we used the hygroscopic parameters and the densities of the organic fraction of the particles derived from the closure study (i.e. $\kappa_{\text {org }}=0.03$, $\rho_{\text {org }}=1300 \mathrm{~kg} \mathrm{~m}^{-3}$ and $\kappa_{\text {org }}=0.1, \rho_{\text {org }}=1400 \mathrm{~kg} \mathrm{~m}^{-3}$ for the flights conducted on 1 and 4 September, respectively; cf. Sect. 3.1.3 and Fig. 6), and assumed that all the samples were internally mixed. During the flight on 1 September (Fig. 9), the hygroscopic parameter ranged from 0.19 to 0.84 , with a median value of 0.31 . The hygroscopic parameter $\kappa_{\text {mix }}$ within the MABL (i.e. up to $1 \mathrm{~km}$ a.s.l.) exhibited a decreasing trend with increasing altitude over the southern and central Aegean Sea (Fig. 9a-c). At higher altitudes $\kappa_{\text {mix }}$ showed a noticeably higher variability, with values ranging from 0.21 at lower altitudes to 0.84 at altitudes above $4 \mathrm{~km}$ where the particles were highly acidic. The vertical variability of $\kappa_{\text {mix }}$ over the northern Aegean Sea was significantly lower, having values that ranged from 0.19 to 0.38 . Overall, the hygroscopic parameter $\kappa_{\text {mix }}$ below the MABL was higher over the southern Aegean sea due to the influence of air masses arriving from the wider Athens region, as described in Sect. 3.2.1.

The vertical profiles of the hygroscopic parameters predicted for the flight on 4 September are shown in Fig. 10. In this case, the calculated $\kappa_{\text {mix }}$ values ranged from 0.22 to 0.80 , with a median value of 0.36 , which is comparable to that calculated for the first flight. However, the vertical variability of $\kappa_{\text {mix }}$ for altitudes even up to $2-3 \mathrm{~km}$ was significantly lower compared to that observed during the first flight. The median value of $\kappa_{\text {mix }}$ was of the order of 0.3 for the whole region as a result of the low acidity (i.e. the inorganic fraction of the particles was mostly ammonium sulfate) and relatively low organic volume fractions of the particles. The variability of $\kappa_{\text {mix }}$ was higher at higher altitudes, with values reaching up to 0.80 . This increase is explained by the increasing acidity of the particles, i.e. their higher volume fraction of sulfuric acid with increasing altitude, as shown in Fig. 8a.

Despite the part that the measurements are performed in a marine environment of the Aegean Sea, the estimated median $\kappa_{\text {mix }}$ values, during both flights, reside well within the range measured in urban and rural regions (Wex et al., 2010) and modelled by for continental Europe (Pringle et al., 2010). 

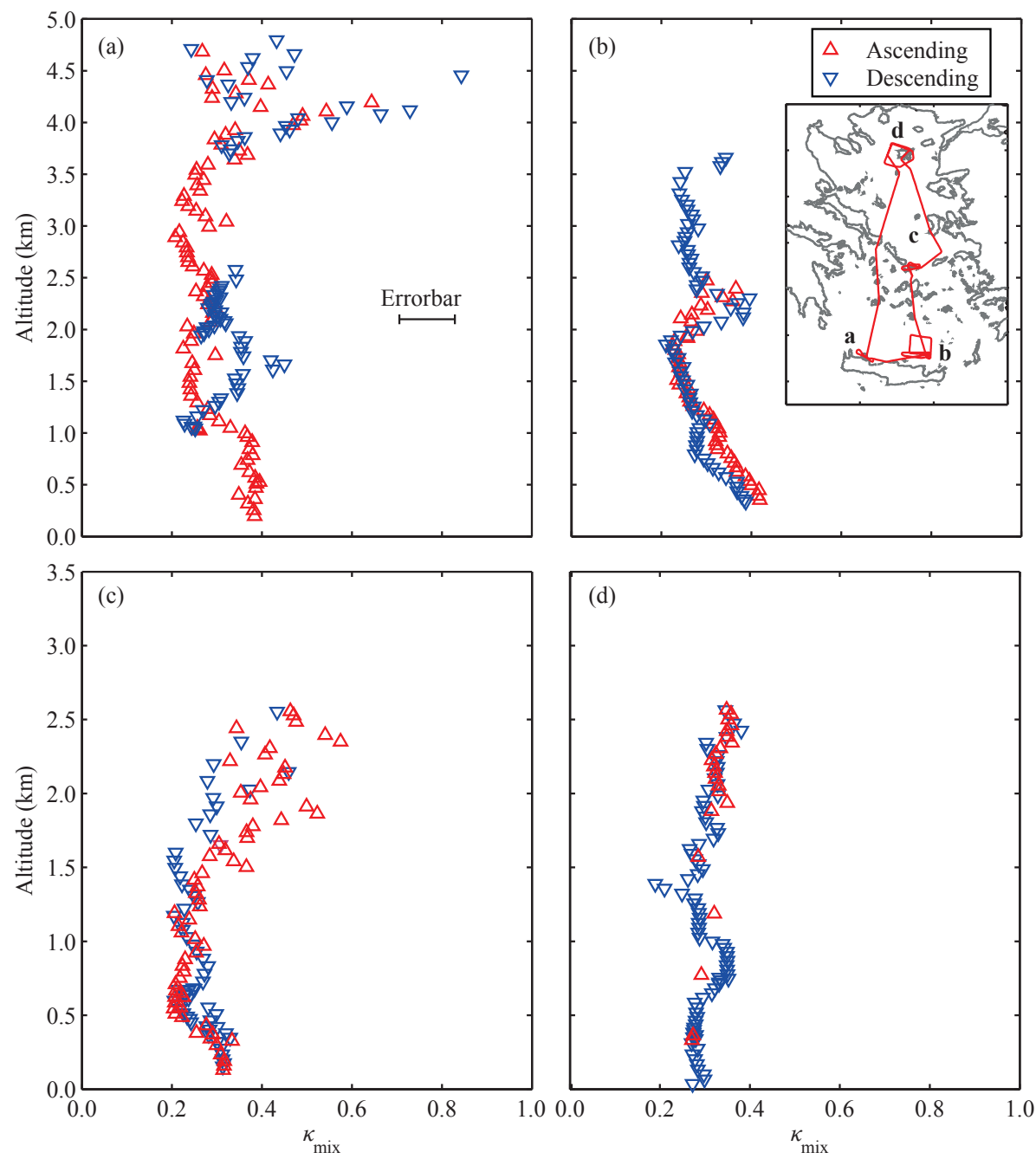

Fig. 9. Vertical profiles of the estimated hygroscopic parameters $\kappa_{\text {mix }}$ of aerosol particles observed over southwestern (a) southeastern (b), central (c) and northern (d) Aegean Sea, during ascends (up triangles) and descends (down triangles) performed on the flight of 1 September 2011 (flight b637). The inset shows the locations corresponding to the vertical profiles of $\kappa_{\operatorname{mix}}$ shown in the different subplots. The hygroscopic parameters are calculated using the $\kappa$-Köhler theory (Eq. 3) and the bulk chemical composition measurements from the airborne cToF-AMS. For the calculations we assumed that the particles were internally mixed, and that all the organic species had $\kappa_{\text {org }}=0.03$ and $\rho_{\text {org }}=1300 \mathrm{~kg} \mathrm{~m}^{-3}$. The error bar represents the spread of the estimated $\kappa_{\text {mix }}$ values when adopting the level of uncertainty used in our closure study.

\section{Conclusions}

Measurements of the chemical composition and hygroscopicity of atmospheric particles were conducted over the region of the Aegean Sea using a cToF-AMS onboard the FAAM BAe-146 aircraft, and a ground-based HTDMA system located on a remote station on the island of Lemnos. The HTDMA measurements showed that the mean hygroscopic growth factor of particles having dry diameters from 50 to $170 \mathrm{~nm}$ was ca. 1.2 , and that the aerosol samples were internally mixed during the entire period of the campaign. Good closure between cToF-AMS and HTDMA measurements was achieved when the aircraft flew in the vicinity of the ground station. For these cases, the most representative values of $\kappa_{\text {org }}$ and $\rho_{\text {org }}$ were respectively 0.03 and $1300 \mathrm{~kg} \mathrm{~m}^{-3}$ for the flight on 1 September (b637), and 0.10 and $1400 \mathrm{~kg} \mathrm{~m}^{-3}$ for the flight on 4 September (b641).

The particles observed over the wider region of the Aegean Sea during the two flights exhibited high variability in their acidity and organic volume fraction, which can be attributed to differences in the origin of the air masses arriving in the region. During the flight conducted on 1 September, the air masses arriving over the northern and central Aegean Sea had origins ranging from eastern Europe, the Black Sea, and the Balkans, while those arriving over Crete had passed near the city of Athens, transferring anthropogenic emissions. During 

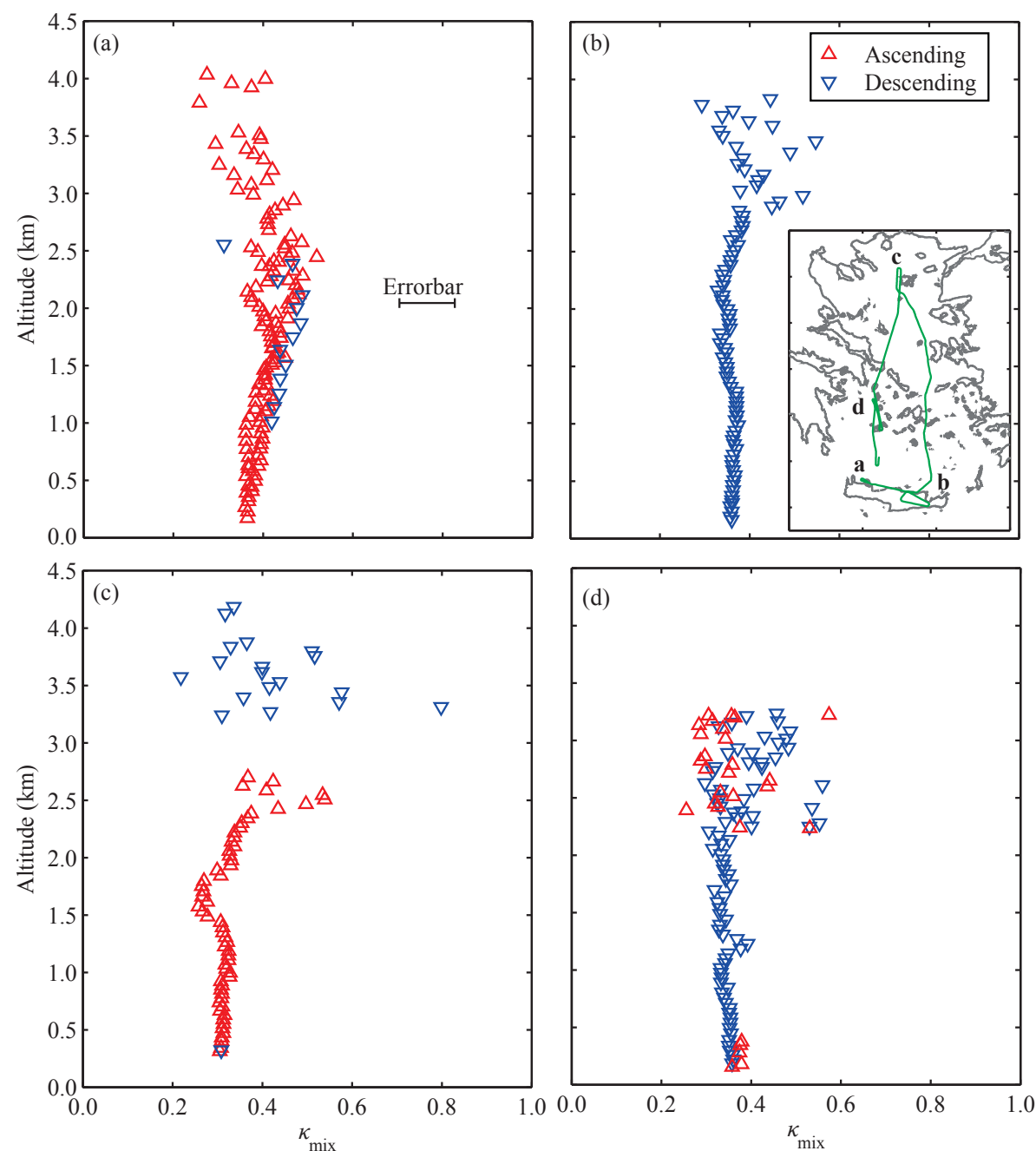

Fig. 10. Vertical profiles of the estimated hygroscopic parameters $\kappa_{\operatorname{mix}}$ of aerosol particles observed over southwestern (a) southeastern (b), central (c) and northern (d) Aegean Sea, during ascends (up triangles) and descends (down triangles) performed on the flight of 4 September 2011 (flight b641). The inset shows the locations corresponding to the vertical profiles of $\kappa_{\mathrm{mix}}$, shown in the different subplots. The hygroscopic parameters are calculated using the $\kappa$-Köhler theory (Eq. 3) and the bulk chemical composition measurements from the airborne cToF-AMS. For the calculations we assumed that the particles were internally mixed, and that all the organic species had $\kappa_{\text {org }}=0.1$ and $\rho_{\text {org }}=1400 \mathrm{~kg} \mathrm{~m}^{-3}$. The error bar represents the spread of the estimated $\kappa_{\text {mix }}$ values when adopting the level of uncertainty used in our closure study.

the flight conducted on 4 September, air masses originated mainly from western and central Europe and the wind patterns were more uniform and representative of the summer period in the region. For both flights we observed that the organic species accounted for almost $50 \%$ of the volume of the particles, and that their acidity increased with increasing altitude. Higher spatial uniformity of the chemical composition of the particles was observed during the second flight as a result of the low variability in the origin and the paths of the air masses arriving in the region. The acidity of the particles observed during that flight was significantly high at high altitudes, exhibiting $\mathrm{H}_{2} \mathrm{SO}_{4}$ volume fractions of up to 0.4 .
Using the particle parameters $\kappa_{\text {org }}$ and $\rho_{\text {org }}$ obtained from the closure study when the aircraft flew in the vicinity of the ground station, the cToF-AMS chemical composition measurements were used to estimate vertical profiles of the aerosol single hygroscopic parameter $\kappa_{\text {mix }}$. Although the median hygroscopic parameter was not significantly different for both flights (i.e. 0.31 and 0.36 during the flights on 1 and 4 September, respectively), its vertical variability was higher during the first flight. This can be explained by the high diversity in the origin of the air masses arriving in the study region, and the contribution of polluted air from the wider Athens area over the southern Aegean Sea during that flight. Despite that the measurements were performed in a the 
marine environment of the Aegean Sea, the estimated median hygroscopic parameters were more representative of continental aerosol particles.

\section{Supplementary material related to this article is available online at http://www.atmos-chem-phys.net/13/ 11595/2013/acp-13-11595-2013-supplement.zip.}

Acknowledgements. The airborne measurements reported in this work have been supported by the EUFAR (227159) EC grant agreement under the Aegean-Game-2 project. Airborne data were obtained using the BAe-146-301 Atmospheric Research Aircraft (ARA) flown by Directflight Ltd and managed by the Facility for Airborne Atmospheric Measurements (FAAM), which is a joint entity of the Natural Environment Research Council (NERC) and the Met Office. The ground measurements have been co-financed by the European Union (European Social Fund - ESF) and Greek national funds through the operational program "Education and Lifelong Learning" of the National Strategic Reference Framework (NSRF) - research funding program: Heracleitus II, Investing in knowledge society through the European Social Fund.

Edited by: U. Baltensperger

\section{References}

Aiken, A. C., Decarlo, P. F., Kroll, J. H., Worsnop, D. R., Huffman, J. A., Docherty, K. S., Ulbrich, I. M., Mohr, C., Kimmel, J. R., Sueper, D., Sun, Y., Zhang, Q., Trimborn, A., Northway, M., Ziemann, P. J., Canagaratna, M. R., Onasch, T. B., Alfarra, M. R., Prévôt, A. S. H., Dommen, J., Duplissy, J., Metzger, A., Baltensperger, U., and Jimenez, J. L.: O/C and OM/OC ratios of primary, secondary, and ambient organic aerosols with high-resolution time-of-flight aerosol mass spectrometry, Environ. Sci. Technol., 42, 4478-4485, 2008.

Allan, J. D., Jimenez, J. L., Williams, P. I., Alfarra, M. R., Bower, K. N., Jayne, J. T., Coe, H., and Worsnop, D. R.: Quantitative sampling using an aerodyne aerosol mass spectrometer -1 . Techniques of data interpretation and error analysis, J. Geophys. Res.Atmos., 108, 4090, doi:10.1029/2002JD002358, 2003.

Allan, J. D., Coe, H., Bower, K. N., Alfarra, M. R., Delia, A. E., Jimenez, J. L., Middlebrook, A. M., Drewnick, F., Onasch, T. B., Canagaratna, M. R., Jayne, J. T., and Worsnop, D. R.: A generalised method for the extraction of chemically resolved mass spectra from aerodyne aerosol mass spectrometer data, J. Aerosol Sci., 35, 909-922, 2004.

Biskos, G., Paulsen, D., Russell, L. M., Buseck, P. R., and Martin, S. T.: Prompt deliquescence and efflorescence of aerosol nanoparticles, Atmos. Chem. Phys., 6, 4633-4642, doi:10.5194/acp-64633-2006, 2006a.

Biskos, G., Russel, L. M., Buseck, P. R., and Martin, S. T.: Nanosize effect on the hygroscopic growth factor of aerosol particles, Geoph. Res. Lett., 33, L07801, doi:10.1029/2005GL025199, 2006b.

Biskos, G., Buseck, P. R., and Martin, S. T.: Hygroscopic growth of nucleation-mode acidic sulfate particles, J. Aerosol Sci., 40, 338-347, 2009.
Canagaratna, M. R., Jayne, J. T., Jimenez, J. L., Allan, J. D., Alfarra, M. R., Zhang, Q., Onasch, T. B., Drewnick, F., Coe, H., Middlebrook, A., Delia, A., Williams, L. R., Trimborn, A. M., Northway, M. J., DeCarlo, P. F., Kolb, C. E., Davidovits, P., and Worsnop, D. R.: Chemical and microphysical characterization of ambient aerosols with the aerodyne aerosol mass spectrometer, Mass Spectrom. Rev., 26, 185-222, 2007.

Clarisse, L., Clerbaux, C., Dentener, F., Hurtmans, D., and Coheur, P.-F.: Global ammonia distribution derived from infrared satellite observations, Nature Geosci., 2, 479-483, 2009.

Clegg, S. L., Brimblecombe, P., and Wexler, A. S.: Thermodynamic model of the system $\mathrm{H}^{+}-\mathrm{NH}_{4}^{+}-\mathrm{SO}_{4}^{2-}-\mathrm{NO}_{3}-\mathrm{H}_{2} \mathrm{O}$ at tropospheric temperatures, J. Phys. Chem. A, 102, 2137-2154, 1998.

Drewnick, F., Hings, S. S., DeCarlo, P., Jayne, J. T., Gonin, M., Fuhrer, K., Weimer, S., Jimenez, J. L., Demerjian, K. L., Borrmann, S., and Worsnop, D. R.: A new time-of-flight aerosol mass spectrometer (TOF-AMS)-instrument description and first field deployment, Aerosol Sci. Tech., 39, 637-658, 2005.

Duplissy, J., DeCarlo, P. F., Dommen, J., Alfarra, M. R., Metzger, A., Barmpadimos, I., Prevot, A. S. H., Weingartner, E., Tritscher, T., Gysel, M., Aiken, A. C., Jimenez, J. L., Canagaratna, M. R., Worsnop, D. R., Collins, D. R., Tomlinson, J., and Baltensperger, U.: Relating hygroscopicity and composition of organic aerosol particulate matter, Atmos. Chem. Phys., 11, 11551165, doi:10.5194/acp-11-1155-2011, 2011.

Engelhart, G. J., Hildebrandt, L., Kostenidou, E., Mihalopoulos, N., Donahue, N. M., and Pandis, S. N.: Water content of aged aerosol, Atmos. Chem. Phys., 11, 911-920, doi:10.5194/acp-11911-2011, 2011.

Foltescu, V. L., Selin, E., and Below, M.: Corrections for particle losses and sizing errors during aircraft aerosol sampling using a rosemount inlet and the pms las-x, Atmos. Environ., 29, 449453, 1995.

Gysel, M., Crosier, J., Topping, D. O., Whitehead, J. D., Bower, K. N., Cubison, M. J., Williams, P. I., Flynn, M. J., McFiggans, G. B., and Coe, H.: Closure study between chemical composition and hygroscopic growth of aerosol particles during TORCH2, Atmos. Chem. Phys., 7, 6131-6144, doi:10.5194/acp-7-61312007, 2007.

Gysel, M. McFiggans, G.B. Coe, H.: Inversion of tandem differential mobility analyser (TDMA) measurements, J. Aerosol Sci., 40, 134-151, 2009.

Hallquist, M., Wenger, J. C., Baltensperger, U., Rudich, Y., Simpson, D., Claeys, M., Dommen, J., Donahue, N. M., George, C., Goldstein, A. H., Hamilton, J. F., Herrmann, H., Hoffmann, T., Iinuma, Y., Jang, M., Jenkin, M. E., Jimenez, J. L., Kiendler-Scharr, A., Maenhaut, W., McFiggans, G., Mentel, Th. F., Monod, A., Prévôt, A. S. H., Seinfeld, J. H., Surratt, J. D., Szmigielski, R., and Wildt, J.: The formation, properties and impact of secondary organic aerosol: current and emerging issues, Atmos. Chem. Phys., 9, 5155-5236, doi:10.5194/acp-9-51552009, 2009.

Haywood, J. and Boucher, O.: Estimates of the direct and indirect radiative forcing due to tropospheric aerosols: a review, Rev. Geophys., 38, 513-543, 2000.

Heintzenberg J.: Fine particles in the global troposphere - A review, Tellus B, 41, 149-160, 1989. 
Hussein, T., Maso, M. D., Petäjä, T., Koponen I. S., and Paatero, P.: Evaluation of an automatic algorithm for fitting the particle number size distributions, Boreal Environ. Res., 10, 337-355, 2005.

Kalivitis, N., Birmili, W., Stock, M., Wehner, B., Massling, A., Wiedensohler, A., Gerasopoulos, E., and Mihalopoulos, N.: Particle size distributions in the Eastern Mediterranean troposphere, Atmos. Chem. Phys., 8, 6729-6738, doi:10.5194/acp-8-67292008, 2008.

Koulouri, E., Saarikoski, S., Theodosi, C., Markaki, Z., Gerasopoulos, E., Kouvarakis, G., Mäkelä, T., Hillamo, R., and Mihalopoulos, N.: Chemical composition and sources of fine and coarse aerosol particles in the eastern Mediterranean, Atmos. Environ., 42, 6542-6550, 2008.

Knutson, E. O. and Whitby, K. T.: Aerosol classification by electric mobility: apparatus, theory, and applications, J. Aerosol Sci., 6, 443-451, 1975.

Kreidenweis, S. M., Petters, M. D., and DeMott, P. J.: Single parameter estimates of aerosol water content, Environ. Res. Lett., 3, 035002, doi:10.1088/1748-9326/3/3/035002, 2008.

Lelieveld, J., Berresheim, H., Borrmann, S., Crutzen, P. J., Dentener, F. J., Fisher, H., Feichter, J., Flatau, P. J., Heland, J., Holzinger, R., Korrmann, R., Lawrence, M. G., Levin, Z., Markowitz, K. M., Mihalopoulos, N., Minikin, A., Ramanathan, V., de Reus, M., Roelofs, G. J., Scheeren, H. A., Sciare, J., Schlager, H., Schultz, M., Siegmund, P., Steil, B., Stephanou, E. G., Stier, P., Traub, M., Warneke, C., Williams, J., and Ziereis, H.: Global air pollution crossroads over the Mediterranean, Science, 298, 794-799, 2002.

Liu, P. S. K., Deng, R., Smith, K. A., Williams, L. R., Jayne, J. T., Canagaratna, M. R., Moore, K., Onasch, T. B., Worsnop, D. R., and Deshler, T.: Transmission efficiency of an aerodynamic focusing lens system: comparison of model calculations and laboratory measurements for the aerodyne aerosol mass spectrometer, Aerosol Sci. Tech., 41, 721-733, 2007.

Marcolli, C., Luo, B. P. and Peter, T.: Mixing of the organic aerosol fractions: liquids as the thermodynamically stable phases, J. Phys. Chem. A, 108, 2216-2224, 2004.

Middlebrook, A. M., Bahreini, R., Jimenez, J. L., and Canagaratna, M. R.: Evaluation of composition-dependent collection efficiencies for the aerodyne aerosol mass spectrometer using field data, Aerosol Sci. Tech., 46, 258-271, 2012.

Mihalopoulos, N., Stephanou, E., Kanakidou, M., Pilitsidis, S., and Bousquet, P.: Tropospheric aerosol ionic composition above the eastern Mediterranean area, Tellus B 49, 314-326, 1997.

Morgan, W. T., Allan, J. D., Bower, K. N., Highwood, E. J., Liu, D., McMeeking, G. R., Northway, M. J., Williams, P. I., Krejci, R., and Coe, H.: Airborne measurements of the spatial distribution of aerosol chemical composition across Europe and evolution of the organic fraction, Atmos. Chem. Phys., 10, 4065-4083, doi:10.5194/acp-10-4065-2010, 2010.

Ogren, J. and Charlson, J.: Implications for models and measurements of chemical inhomogenities among cloud droplets, Tellus B, 44, 489-504, 1992.

Park, K., Kim, J. S., and Miller, A. L.: A study on effects of size and structure on hygroscopicity of nanoparticles using a tandem differential mobility analyzer and TEM, J. Nanopart. Res., 11, 175-183, 2009.

Petters, M. D. and Kreidenweis, S. M.: A single parameter representation of hygroscopic growth and cloud condensation nucleus activity, Atmos. Chem. Phys., 7, 1961-1971, doi:10.5194/acp-71961-2007, 2007.

Pikridas, M., Bougiatioti, A., Hildebrandt, L., Engelhart, G. J., Kostenidou, E., Mohr, C., Prévôt, A. S. H., Kouvarakis, G., Zarmpas, P., Burkhart, J. F., Lee, B.-H., Psichoudaki, M., Mihalopoulos, N., Pilinis, C., Stohl, A., Baltensperger, U., Kulmala, M., and Pandis, S. N.: The Finokalia Aerosol Measurement Experiment - 2008 (FAME-08): an overview, Atmos. Chem. Phys., 10, 6793-6806, doi:10.5194/acp-10-6793-2010, 2010.

Pilinis, C. and Seinfeld, J. H.: Continued development of a general equilibrium model for inorganic multicomponent atmospheric aerosols, Atmos. Environ., 21, 2453-2466, 1987.

Pringle, K. J., Tost, H., Pozzer, A., Pöschl, U., and Lelieveld, J.: Global distribution of the effective aerosol hygroscopicity parameter for CCN activation, Atmos. Chem. Phys., 10, 52415255, doi:10.5194/acp-10-5241-2010, 2010.

Rader, D. J. and McMurry, P. H.: Application of the tandem differential mobility analyzer to studies of droplet growth or evaporation, J. Aerosol Sci., 17, 771-787, 1986.

Salisbury, G., Williams, J., Holzinger, R., Gros, V., Mihalopoulos, N., Vrekoussis, M., Sarda-Estéve, R., Berresheim, H., von Kuhlmann, R., Lawrence, M., and Lelieveld, J.: Ground-based PTR-MS measurements of reactive organic compounds during the MINOS campaign in Crete, July-August 2001, Atmos. Chem. Phys., 3, 925-940, doi:10.5194/acp-3-925-2003, 2003.

Spengler, J. D., Brauer, M., and Koutrakis, P.: Acid air and health, Environ. Sci. Technol., 24, 946-955, 1990.

Stock, M., Cheng, Y. F., Birmili, W., Massling, A., Wehner, B., Müller, T., Leinert, S., Kalivitis, N., Mihalopoulos, N., and Wiedensohler, A.: Hygroscopic properties of atmospheric aerosol particles over the Eastern Mediterranean: implications for regional direct radiative forcing under clean and polluted conditions, Atmos. Chem. Phys., 11, 4251-4271, doi:10.5194/acp11-4251-2011, 2011.

Stolzenburg, M. R. and McMurry, P. H.: TDMAFIT user's manual, Particle Technology Laboratory, Department of Mechanical Engineering, Univercity of Minnesota, Minneapolis, 1-61, 1988.

Stolzenburg, M. R. and McMurry, P. H.: An ultrafine aerosol condensation nucleus counter, Aerosol Sci. Technol., 14, 48-65, 1991.

Tombrou, M., Bossioli, E., Kalogiros, J., Allan, J., Bacak, A., Biskos, G., Coe, H.,Dandou, A., Kouvarakis, G., Mihalopoulos, N., Protonotariou, A. P., Szabó-Takács, B., and Triantafillou, E.: Physical and chemical processes of polluted air masses during etesians: Aegean-Game airborne campaign - an outline, in advances in meteorology, climatology and atmospheric physics, Springer Atmospheric Sciences, 1239-1244, SpringerVerlag Berlin Heidelberg, 2012.

Wang, C. S. and Flagan C. R.: Scanning electrical mobility spectrometer, Aerosol Sci. Technol., 13, 230-240, 1990.

Wang, X., Kruis, F. E., and McMurry, P. H.: Aerodynamic focusing of nanoparticles: I. Guidelines for designing aerodynamic lenses for nanoparticles, Aerosol Sci. Tech., 39, 611-623, 2005.

Wex, H., McFiggans, G., Henning, S., and Stratmann, F.: Influence of the external mixing state of atmospheric aerosol on derived CCN number concentrations, Geophys. Res. Lett., 37, L10805, doi:10.1029/2010GL043337, 2010. 